\title{
Understanding today's Kurdish movement: Leftist heritage, martyrdom, democracy and gender
}

Marlies Casier and Joost Jongerden

\section{(2) OpenEdition \\ Journals}

Electronic version

URL: http://journals.openedition.org/ejts/4656

DOI: $10.4000 /$ ejts.4656

ISSN: $1773-0546$

Publisher

EJTS

Electronic reference

Marlies Casier and Joost Jongerden, « Understanding today's Kurdish movement: Leftist heritage, martyrdom, democracy and gender », European Journal of Turkish Studies [Online], 14 | 2012, Online since 18 January 2013, connection on 16 February 2020. URL : http://journals.openedition.org/ejts/ 4656 ; DOI : $10.4000 /$ ejts.4656

This text was automatically generated on 16 February 2020.

(C) Some rights reserved / Creative Commons license 


\title{
Understanding today's Kurdish movement: Leftist heritage, martyrdom, democracy and gender
}

\author{
Marlies Casier and Joost Jongerden
}

1 Though an important political actor in Turkey, and also in Syria, Iraq and Iran, there are few detailed socio-political accounts of the Kurdish movement's main political actor in Turkey, the Partiya Karkêren Kurdistan (Kurdistan Workers' Party or PKK). This may be considered an important demerit of not only Kurdish and Turkish Studies but social and political sciences in general. In this special issue, we aim to address what may be less a gap in the literature than an academic blind-spot. Without attempting to be allencompassing, what we offer here is an inquiry into the Kurdish movement's ideological production, engaging the PKK's perspectives on the revolutionary left, gender and political Islam, both delving into contemporary issues as well as issues related to the 1970s, the period during which the PKK emerged, and the political configurations of the years that preceded its establishment as an organized party.

The idea for a special issue on the Kurdish movement developed in 2010, following a panel organized at the Middle East Studies Association (MESA) in Boston. At this panel Leftists after all? The Kurdish Movement in Turkey and the Left, from the 1960s to the 2000s- we started from the premise that the Kurdish movement in Turkey has never been easy to categorize. Kurdish political movements and organizations are easily labeled 'Kurdish nationalist', yet their political history, external relationships, discourses and practices complicate the Kurdish nationalist stamp. This is particularly true for the PKK, which emerged from the revolutionary left in Turkey, and over the years invested in relations with the left, engaged in Marxist political debates in the 1970s, developed a postMarxist and en-gendered political discourse in the 1990s and 2000s, and built political alliances with leftist parties while consciously trying not to estrange religious-inspired organizations. In this issue, we bring together several contributions, each of them entering today's Kurdish movement from a different angle, and as such, through these various lenses, contributing to a political and sociological understanding of its main 
actor, the PKK. Looking into the way it has been giving meaning to the world and itself, it is the ideological production and the deployment of the discursive repertoires that will be central to this thematic issue. Attention will consequently be paid to the movement's leftist and secular roots and imprint and how these have been adapted and transformed over time. Identity politics will figure as important, but Akkaya and Jongerden argue in their contribution to this issue (Re-assembling the political, the PKK and the project of radical democracy) that the PKK imagines identity politics beyond identity politics. It is a politics which has to render i) visible the subordinations of identity, ii) challenge the structures of domination using the subordinated identity as a weapon in the quest for freedom, and iii) goes beyond identity politics by assembling Kurdish identity demands into a project of radical democracy.

3 This type of inquiry of contemporary political movements is a type of inquiry which we hope might serve as an incentive for more future comparative research on insurgent movements and their identity politics. Gambetti's comparative study of the Kurdish movement and the Zapatistas in Mexico's Chiapas (Gambetti 2009) as well as Casier's analysis of the Kurdish movements' involvement with the Global Justice Movement and their social forums (Casier 2011) can, with regards to our case of the Kurdish movement, be considered contributions to such a comparative research agenda.

\section{A political sociological understanding of the Kurdish movement}

Most of the academic literature on the PKK does not attempt to understand the movement, but tries to show the PKK as an expression of something else. Unsurprisingly, a significant part of the academic literature on the PKK is written from the perspective of criminology (Kubera 1999; Roth and Sever 2007; Walter and Fricke 1988) and of terrorism and counter-insurgency (Demir 2008; Roth and Sever 2007; Ünal 2012), or a convergence of the two. Roth and Sever (2007) take as their starting position the position that 'Scholars have long recognized that terrorist groups have engaged in transnational organized crime activities,' and, engaging with the question of when a terrorist organisation becomes a transnational organized criminal organisation, attempt to develop an answer from the perspective of the need for resources. Others have focussed on learning capacities. According to Demir (2008), 'Terrorist organizations need to change their behaviours, because they operate in a fast changing, threatening and competitive environment' and thus 'must adapt and improve by changing [their] organizational structure, functions, discourses and actions.' This is also a key-interest of Eccarius-Kelly (2012), who makes a comparison between the PKK and Fuerzas Armadas Revolucionarias de Colombia (Revolutionary Armed Forces of Colombia or FARC), and discusses the ability of these two organizations to adapt to changing conditions.

Bacik (2011) relates the 'rampant PKK insurgency' to the failure of Turkey to propose an effective political solution for the Kurdish problem and an insistence on dealing with the PKK through militaristic methods, thereby worsening 'the Kurdish problem by creating deeper social problems.' This line of reasoning is questioned by Tezcür (2010), who argues that greater political openness may spark new rounds of violence, because the insurgents, in this case the PKK, fear marginalization. The author bases this argument on the assumption that 'no Turkish politician can enter into direct 
negotiations with the Kurdish nationalist movement without taking enormous political risks that may doom his or her career' (ibid.: 787) - an assumption, it may be noted, which stands square to information about numerous talks held between the PKK and representatives of Turkey, both inside Turkey and in Oslo, Norway (to the point, recently, of becoming public knowledge and defended by the Prime Minister). Aydinl (2002), too, makes a linkage between political liberalization and a return to combat, but links this to an attempt to detach the Kurdish issue from the PKK. He identifies three problematic factors in this respect: i) the difficulty of 'creating' a non-PKK dominated or at least, very heavily influenced - Kurdish political representation and thus sidelining the PKK and the Kurdish issue; ii) a rise in political legitimacy of the PKK in the post-2000 era because of its emphasis on Kurdish political rights, and iii) the Turkish security environment which is designed to defeat the PKK by military means, which, it may again be noted, not only fails but also provokes popular resistance and prompts public support for the organization (Aydınlı 2002: 221). Various authors have pointed towards a rapid decline in strength of the PKK and the PKK's shrinkage, mainly focussing on the PKK's armed strength inside Turkey and on PKK's number of guerrillas (Radu 2001: 47; Özcan 2006b: 120). The PKK's strength, however, can hardly be measured in terms of the number of its armed members. First and foremost, the PKK is a political organization: 'The violence they perpetrated was rational/instrumental, in the sense that it sought to change the political and juridical status [of the Kurds]' (Bozarslan 2004: 23).

6 The first serious attempt at understanding the PKK from a more political sociological point of view was made by a Turkish Daily News journalist. In The PKK: a report on separatist violence in Turkey (1973-1992), Ismet Imset (1992) gave a detailed account of the political backgrounds of the PKK. Contrary to the usual, but inaccurate, framing of the PKK as an ethnic and/or nationalist organization, Imset firmly positioned the PKK in the history of the revolutionary left in Turkey. Around the same time Imset published his book on the PKK, another Turkish journalist, Mehmet Ali Birand (1992), published Apo ve PKK. The book is based upon interviews conducted with Abdullah Öcalan in 1988 and 1991, and the importance of the book lies not so much its analysis of the PKK, but in the space it gave to PKK leader Abdullah Öcalan to explain the PKK. In 1999 Ali Nihat Özcan published PKK (Kürdistan İş̧i Partisi) tarihi, ideolojisi ve yöntemi, considered one of the first PhDs on the PKK conducted at a Turkish University (the Dokuz Eylül University). Later, following the capture of Öcalan and the organizational and ideological changes within the PKK, two more Turkish publications are worth mentioning. The first one is Hangi PKK written by Fikret Bila (2004), discussing the discourse change within the PKK, which preceded the re-establishment of the PKK, and wherein it denounced state-building, and proclaimed radical democracy as its political project. ${ }^{1}$ In Turkey's Kurds, a theoretical analysis of the PKK and Abdullah Öcalan (2006), Ali Kemal Özcan, as Ismet Imset, positions the PKK within the history of the revolutionary left. This positioning of the PKK within the history of the revolutionary left is also the main theme of Born from the left: the making of the PKK (Jongerden and Akkaya 2011). While Imset's journalistic account is more an organizational overview, Jongerden and Akkaya approach the relationship between the revolutionary left and the PKK on the basis of biographical information and an analysis of political discourses, as they do also in this issue, wherein they discuss the political heritage and commemoration of Haki Karer (see below) in the context of the relations of Kurdistan Revolutionaries and the left in Turkey. 
7 Strikingly, another journalist has contributed an important book on the PKK along similar lines, Blood and Belief: the PKK and the Kurdish fight for independence (2007). This work discusses party formation and PKK milestones, but, more than that, sheds light on the social construction of the PKK as a political party. In doing so, Aliza Marcus shows how recruitment should not be understood as a product of force, but as a process of conviction and conversion. Recruitment methods, for example, include intensive, oneto-one meetings to win people over to the cause. Through the eyes of those who have participated, we get to learn about the PKK, and its political and military struggle from the inside. In another study, The Kurdish national movement in Turkey, Cengiz Güneş discusses the PKK's political transformation in the context of the development of the Kurdish movement in Turkey since the 1960s. Initially, a progressive realization of the possibility of a right to self-determination was considered in terms of secession; later, cautiously explored in the 1990s, and decidedly articulated in the 2000s, the PKK defined the right to self-determination in three inter-related projects - democraticrepublic, democratic-autonomy and democratic-confederalism - in which issues of secession are substantially by-passed in the concern for a genuine (local, ground-up) democracy. This political transformation is further discussed with a contribution on the PKK and radical democracy in this issue, that relates the ideological transformations of the international left in the post-cold war era.

8 The overall aim of this special issue is to contribute to a constructivist political sociological understanding of the PKK, engaging with its discursive repertoires and the way these have served the movement to mobilize men and women, Kurds and people within Turkey's Left. The contributions by Akkaya and Jongerden and çağlayan bear testimony to the ways in which the ideologues of the PKK have tapped into and tried to mould or re-conceptualize Marxist and feminist streams of thought. Through these exercises the PKK has sought to redefine and redirect its goals. In articles that analyse the strategic rationale behind the discursive repertoires the movement developed, Çağlayan and Gurbuz also look at how the ideological discourses continue to direct the movement's militants' actions and processes of decision-making. This is a topic which, if researched more intensively, would benefit not only our understanding of the PKK but our understanding of insurgency movements more generally. In the articles to this thematic issue (Akkaya and Jongerden, Gurbuz and Çağlayan) we find a demonstration of how the discursive repertoires allow for the ongoing (re)positioning of the PKK. Çağlayan, in her contribution to this issue, shows how gender construction in the political discourse of the PKK also served to engage women in the political struggle.

9 The interview by Olivier Grojean and Marlies Casier with historian and political scientist Hamit Bozarslan inquires the shared history of Turkey's Kurdish movement and the Turkish Left, lending insight into how the former grew close to the Left at first, yet carved out a distinct political space for itself thereafter. Bozarslan also places the leftist heritage of the Kurdish movement in Turkey firmly within an international perspective, by contrasting it with the developments in the Middle East of the 1950s to the 2000s, in particular in neighbouring Iraq, but also in Egypt e.g. and recalling simultaneous revolutionary leftist mobilization in more distant parts of the world, such as Latin America and Asia.

10 The approach of this issue is thus primarily a political sociological one, seeking to understand the ideological production that drives the political leaders, militants and supporters. This should advance our understanding of their actions and rationale and 
how these have been evolving during the past decades in relation to and in exchange with national and international shifts in the ideological paradigms on and of the Left. Consequently we will witness how the main actors frame and reframe local and regional problems in Turkey and the Middle East at large in terms of colonialism, critiques on nationalism and the nation-state, male domination in society, etc. (on framing see Benford and Snow 2000).

\section{The quest for Turkey's revolutionary Left}

In 'The Kurdistan Workers' Party and a New Left in Turkey: analysis of the revolutionary movement in Turkey through the PKK's memorial text on Haki Karer,' Jongerden and Akkaya make the case that the PKK, from its very beginning, sought to unite the revolutionary left in Turkey in a metaphorical way of speaking. Exemplary of this pursuit is the commemoration of the leftist revolutionary Haki Karer in PKK's discursive repertoires. Killed in 1977, Haki Karer was a founding member of the Kurdistan Revolutionaries, the name under which the organization operated before it assumed the name 'PKK'. Commemorations of Haki Karer and political evaluations of his political heritage highlight a perceived failure on the part of Turkey's Left to properly comprehend the Kurdish issue in Turkey. One of the banners that the Left had been marching behind in the 1970s was one calling for a 'Fully Independent Turkey!' While evaluating the status of Turkey as a semi-colony (of Western capitalist imperialism), the Left had turned a blind eye to Turkey's own role as itself a colonizing country, vis-à-vis Kurdistan. According to the Kurdistan Revolutionaries/PKK, this contradiction had produced Turkish and Kurdish nationalisms, hindering the development of a revolutionary Left in Turkey.

The PKK criticized the Left for not being able to question its Kemalist inheritance, which was understood to prevent it from engaging with a critical reading of Turkey's political reality. The struggle of the Left with its Kemalist heritage stands out also in Bozarslan's account of the historical developments of the relationship between the Kurdish movement and the Left in Turkey, even though some of the leaders of the revolutionary leftist parties of the 1970s were critically engaged with Kemalism and acknowledged the rights of Kurds to determine their own future. In PKK's writings and historiography, Haki Karer has become the embodiment of a new Left personality, which through his liberation from Kemalism is able to become a genuine force of opposition, and to engage in true solidarity with Kurds.

13 At different points, the PKK has sought to set the agenda for progressive politics and unite the Left in Turkey around this. It is worth inquiring, therefore, into today's platforms for cooperation in Turkey and internationally in which the PKK has been involved, not so much directly as in its agenda-setting capacity. Just to list a few examples: since the 1990s, the Turkey Peace Assembly, bringing together human rights activists, journalist, writers, labor unionists and others, has been serving as a platform for joint collective action; in the 2006 general election, the Thousand Hopes Candidate List served as a platform to re-assemble the Left; and since the early 2000s, activists and politicians of the Kurdish movement have been actively involved with the Global Justice Movement. ${ }^{2}$ This engagement with the Global Justice Movement may also be better understood in the light of PKK's ideological and organizational transformation, discussed in the second paper here by Akkaya and Jongerden. 


\section{Beyond statehood and nationalism?}

14 with this reconceptualization of democracy. Through a critique of the state and the socialist experiments of the past, PKK co-founder, long-time leader and architect of this new development Abdullah Öcalan argued in works developed from around the time of his capture and trials that liberation was no longer to be sought through means of state-building but through a deepening of democracy. Practically, the PKK seeks to achieve this through three interrelated projects: a democratic republic, democratic autonomy and democratic confederalism. The democratic republic seeks to redefine the Republic of Turkey, by disassociating democracy from nationalism; democratic autonomy refers to the right of people to decide on their own priorities and policies, to determine their own future; and the project for democratic confederalism is to serve as a model for self-government, its concrete realization sought through the political organization of society at four different levels, namely, communes in villages and districts, the organization of social groups (such as women and youth), organization on the basis of cultural and religious identities, and civil society organizations. By means of these interrelated projects the PKK is attempting to 'reassemble' the political. This implies also a reconstruction of the movement itself and its affiliated organizations, to be effected under the umbrella of the KCK (Koma Civakên Kurdistan, theUnion of Communities in Kurdistan). In this way and to these ends, Akkaya and Jongerden argue, the Kurdish movement has been transforming itself into a multiplicity of interacting institutions that aim at the transformation of society in all aspects, leaving behind the old goals of state capture through armed struggle.

16 The Kurdish movement's involvement with 'identity politics' throws up a range of questions. Öcalan draws upon Negri and Hardt, who argue that radical democracy can be sought by working through identity politics, through a re-appropriation of identity and its deployment as a weapon, while at the same time seeking its abolition. Such a use of identity politics has long been a point of discussion. Can identity truly be used thus, appropriated as a strong mobilizing force that functions politically as a weapon, while at the same time pursuing its abolishment? How is this to be done, being done? Nationalist feelings and idealizations are employed through a variety of representational forms and levels to mobilize the masses in support of the movement. They are part and parcel of the ideology into which militants are being socialized and provide the founding elements for how Kurds supportive of the PKK understand themselves. Whereas 'identity', particularly in terms of the 'nation' or 'people', serves the movement to successfully mobilize and have individuals and groups commit to its 
cause, identity is not self-explanatory. Mustafa Gurbuz's contribution to the issue is a reminder thereof.

In "'Sold out to the enemy": Emerging symbolic boundaries in Kurdish politics and the strategic use of labeling,' Mustafa Gurbuz questions what he regards as the PKK's selective condemnations of leftist personalities for treason. Why is it, he asks, that some influential Kurdish personalities, such as those who endorsed the establishment of the state-run Kurdish television station, are labeled traitors to the Kurdish cause, whereas others or not? Gurbuz makes the case for a symbolic niche perspective for the study of the strategic logic involved in labeling treason. Whereas the PKK created a hegemony over the definition of Kurdishness, the cultural habitats of Kurds have now become arenas of competition. Thus, it is out of fear, of being sidelined, that the PKK and the Barıs ve Demokrasi Partisi (Peace and Democracy Party or BDP) ${ }^{3}$ strategically label Kurdish personalities as traitors, especially those perceived as supportive of the policies of their rival player in the region, the nationally governing Adalet ve Kalkınma Partisi (Justice and Development Party or AKP). Labeling operates as part of the movement's quest to reconstruct the boundaries of collective consciousness. By othering rival players, the PKK and BDP seek to assert their position, in an effort to maintain their 'patent of Kurdishness.'

The interview with Hamit Bozarslan throws another light on the coming into being of the symbolic boundaries of Kurdish politics. Bozarslan argues that by the end of the 1980 s and beginning of the 1990s we witnessed the separation of the Kurdish movement from the Turkish political space, a process, he argues, that has been profoundly nationalist. Nevertheless, while the legal, representative wing of the Kurdish movement, embodied by the Halkin Emek Partisi (People's Labor Party or HEP) and its successors, is, in Bozarslan's words 'before everything a Kurdish party' it is also 'a Kurdish plus a leftwing party,' in support of 'any kind of social struggle,' be it that of trade unions, women's rights or, today, LGBT rights, 'but at the heart there is this Kurdish thickness.'

\section{Defining Kurdishness}

Handan Çağlayan's contribution to this issue bares testimony to the (ongoing) exercise of defining Kurdishness, in particular where she discusses Öcalan's typology of old and new Kurdishness. Through his political discourse on men and women, the PKK's main ideologue has tried to define what it means to be 'a good Kurd.' The AKP's presence amongst its (potential) constituency is considered particularly threatening when it comes to the Kurdish movement's pro-women activities and politics. As Jongerden and Akkaya (2011) have argued elsewhere, the Kurdish nationalist movement conceived of itself from the outset as a modern and revolutionary force for change, intent on doing away with traditional structures of socio-political organization. The conservative AKP constitutes a threat to this transformational project. Very much like the opposition of the Cumhuriyet Halk Partisi (Republican People's Party or CHP) to the current trend in Turkey's social and political life, many Kurdish militants and activists consider the AKP to have a secret agenda, as planning to Islamify public and political space. It is deeply suspicious of and opposed to the basic direction of cultural change in the country, including possible back-pedaling on the move towards gender equality. ${ }^{4}$ It would therefore be particularly interesting to study more closely the local and regional 
spheres of competition between the AKP and the PKK/BDP over the definition of women's roles in public life.

Handan Çağlayan examines the political discourse on women and women's political participation in the Kurdish Movement in her contribution 'From Kawa the Blacksmith to Ishtar the Goddess: Gender constructions in ideological-political discourses of the Kurdish movement in post-1980 Turkey. Possibilities and limits.'By assigning a mission to women, nationalist movements seek to remove the barriers that keep women from participating in the struggle for national liberation, in particular since gender and the roles and meanings assigned to woman and manhood play an important, constitutive role in national imaginaries. At the same time, political engagements by women have the potential to materially affect their positions and thereby change their identities, turning women from symbols into real, empowered political and societal actors. In the Kurdish movement, women were initially called upon in order to increase the number of people taking part in the armed struggle. Çağlayan shows in her contribution that, at the end of the 1980s and the beginning of the 1990s, Öcalan started to tackle the cultural inhibitions, and in particular the concept of 'honor killing' (namus), in his analysis. This led him to develop a critique of the traditional familial attachments and gender relations in terms of 'old Kurdishness' (which effectively extended his more traditional leftist critique of tribal power structures based on inherited leadership and land-ownership). This old Kurdishness is depicted as a position from which each individual is supposed to liberate him or herself in order to create the 'new' and 'free' Kurdishness, as has been elaborated by Grojean (2008). The discourse on women's liberation was reinforced in the 1990s, through the active participation of women in the manifestations of popular protest, the guerilla organization and political parties. This amounted to a situation in which women were no longer objects waiting to be liberated, but active subjects, developing a space of their own within the movement.

Çağlayan believes that the importance attached to women's liberation has prevented the PKK from developing a narrow nationalism once the Marxist framework was dropped, or transcended. It provided the movement with a new universalism, she argues. In the new ideological discourse that emerged in the late 1990s, however, women were reconstituted as goddesses who had to fulfill a constituting mission through sacrifice: the refusal of all love, except the love of homeland. Women consequently found themselves allowed to leave their homes and participate in the public sphere, and yet the patriarchal control continued insofar as what they had to endure moved from the private into the public sphere, with sexuality and earthly relationships (continuing to be) depicted as devaluating women.

\section{Embodying the discursive repertoires: martyrs - manuals}

In Jongerden and Akkaya's contribution to this issue, the commemoration of Haki Karer as a martyr is understood as a means to criticize the Left. Similarly, Çağlayan describes how Zilan, a female martyr within the movement, was brought forward by Öcalan as an example for other women and men of how one is to lead a life truly committed to the goal of liberation (of Kurds). Whereas Karer symbolizes the Left that has freed itself from its Kemalist nationalism, Zilan symbolizes the Kurds that have freed themselves from the 'old Kurdishness' and become a 'New (wo)men.' 
Çağlayan explains how the discourse on women's liberation sought to remove the barriers that kept women from participating, by assigning a mission to women. Similarly the discourse around Haki Karer, glorifying his 'true internationalism', was aimed at removing the barriers that prevented Turkish leftists from participating in the struggle for political and societal change.

In his account of the historical relationships between the Kurdish movement and the Turkish Left, Bozarslan points at two figures whose ideas have accelerated Kurdish militants' break-away from the Turkish Left, İbrahim Kaypakkaya and Sait Kirmizitoprak. Kaypakkaya developed the first criticism of Kemalism as a fascist regime, considering this regime to have been anti-Kurdish and anti-revolutionary from its beginnings. Sait Kırmizitoprak adhered to the thesis that Kurdistan was a colony, which implied that Kurds had to fight an anti-colonial war of liberation/independence. Kırmizitoprak, moreover, openly accused the Turkish Left of being a colonial Left, that is, of not representing the colonized people. It is partly Kirmizitoprak's legacy that contributed to the radicalization of the Kurdish movement and its separation from the Turkish Left in the early seventies, Bozarslan argues.

25 Finally, Bozarslan reminds us of the Fanonian legacy within the PKK. The 'responsibility for slavery lies with the slave and it is his resistance that allows [him] to become a free man,' argues Bozarslan, concluding that 'It is not only about changing the system but about creating a man who frees himself from his chains.' A similar argument had been made by Jongerden and Akkaya (2011) in describing how the PKK evaluated its armed struggle as one that simultaneously attacked both Kurdish enslavement and colonial dictatorship. It is as though we hear Sartre speak.

In his preface to Frantz Fanon's book The Wretched of the Earth (1961), Sartre had written that in the colonies, the violence perpetrated by the colonizers seeks to dehumanize the colonized. Everything is done to wipe out the traditions and culture of the colonized (including their language) and replace them with that of the colonizer. Sartre argued that no gentleness can efface these marks of colonial violence - and that colonial violence could only be destroyed by counter-violence. Without hesitation he argued that to shoot down a colonizer is to kill two birds with one stone, at the same time both destroying an oppressor and releasing the man he oppresses. What remains are a dead man and a free man. This counter-violence is 'man re-creating himself' (Sartre 1961). According to Bozarslan, this is the discourse through which not only the PKK and other Kurdish groups, but also many other organizations fighting colonialism, such as the Palestinians, gave meaning to their struggle and their acts. And this brings us back to the starting point for this issue, to make a contribution to an understanding of the PKK and the Kurdish movement, not from a 'distanced' or ' distant' position, but from the way in which they themselves have been giving meaning to their struggle. This issue is a modest attempt in this direction, but also an invitation to others to work and develop this research agenda. 


\section{BIBLIOGRAPHY}

Aydınl, Ersel (2002) 'Between security and liberalization: decoding Turkey's struggle with the PKK,' Security Dialogue 33(2), pp. 209-225.

Akkaya, Ahmet Hamdi and Joost Jongerden (2011) 'The PKK in the 2000s: Continuity through breaks?' in Casier, Marlies and Jongerden, Joost (eds.), Nationalisms and politics in Turkey: Political Islam, Kemalism and the Kurdish issue, New York: Routledge, pp.143-162.

Bacik, Gökhan (2011) 'The PKK Problem: Explaining Turkey's Failure to Develop a Political Solution,' Studies in Conflict \& Terrorism 34(3), pp.248-265.

Benford, Robert and David Snow (2000) 'Framing processes and social movements: an overview of an assessment,' Annual Review of Sociology 26 (1), pp.611-639

Bila, Fikret (2004) Hangi PKK, Ankara, Ümit Yayıncılık.

Birand, Mehmet Ali (1992) Apo ve PKK. Istanbul, Milliyet Yayınları.

Bozarslan, Hamit (2004) Violence in the Middle East, the political struggle to self-sacrifice. Princeton, NJ: Markus Wiener Publishers.

Casier, Marlies (2011) 'Beyond Kurdistan? The Mesopotamia Social Forum and the appropriation and re-imagination of Mesopotamia by the Kurdish movement,' Journal of Balkan and Near Eastern Studies 13(4), pp.417-432.

Casier, Marlies, Joost Jongerden and Nic Walker (2011) 'Fruitless attempts? The Kurdish initiative and containment of the Kurdish movement in Turkey,' New Perspectives on Turkey 44, pp.103-127 Demir, Cenker Korhan (2008) ‘Öğrenen Örgütler ve Terör Örgütleri Bağlamında PKK,' Uluslararasi Iliskiler 5(19), pp.57-88.

Eccarius-Kelly, Vera (2012) 'Surreptitious Lifelines: A Structural Analysis of the FARC and the PKK,' Terrorism and Political Violence 24(2), pp.235-258.

Gambetti, Zeynep (2009) 'Politics of place/space: the spatial dynamics of the Kurdish and Zapatista movements,' New Perspectives on Turkey 41, pp.43-87.

Grojean, Olivier (2008) 'La production de l'Homme nouveau au sein du PKK', European Journal of Turkish Studies 8, URL: http://ejts.revues.org/index2753.html

Imset, Ismet (1992) The PKK: a report on separatist violence in Turkey (1973-1992), Ankara: Turkish Daily News.

Jongerden, Joost and Ahmet Hamdi Akkaya (2011), 'Born from the Left. The making of the PKK', in Casier, Marlies and Jongerden, Joost (eds.), Nationalisms and Politics in Turkey: political Islam, Kemalism and the Kurdish issue, New York: Routledge, pp.123-142.

Kubera, Thomas (1999) 'The Kurdistan Workers’ Party PKK', Kriminalistik 53(1), pp.27-31.

Marcus, Aliza (2007) Blood and Belief: the PKK and the Kurdish Fight for Independence. New York / London: New York University Press.

Özcan, Ali Kemal (2006a) Turkey's Kurds: a Theoretical Analysis of the PKK and Abdullah Öcalan. London / New York: Routledge.

Özcan, Ali Kemal (2006b) ‘The vacillating PKK: can it be resurrected?', Middle Eastern Studies 43(1), pp.107-124. 
Özcan, Ali Nihat (1999) PKK (Kürdistan İşçi Partisi) tarihi, ideolojisi ve yöntemi. Ankara: ASAM yayınları.

Radu, Michael (2001) 'The rise and fall of the PKK,' Orbis 25(1), pp.47-63.

Roth, Mitchel P. and Murat Sever (2007) 'The Kurdish workers' party (PKK) as criminal syndicate: Funding terrorism through organized crime, a case study,' Studies in Conflict \& Terrorism 30 (10), pp.901-920.

Tezcür, Günes Murat (2010) 'When democratization radicalizes: The Kurdish nationalist movement in Turkey,' Journal of Peace Research 47(6), pp.775-789.

Ünal, Mustafa Cosar (2012) Counterterrorism in Turkey, policy choices and policy effects towards the Kurdistan Workers Party (PKK), London: Routledge.

Walter, Dieter and Gerhard Fricke (1988) 'Execution threatens the opponents - the Kurdische Arbeiterpartei (PKK) and their criminal activities in the Federal Republic of Germany,'

Kriminalistik (7), pp.406-409.

Watts, Nicole F. (2010) Activists in Office: Kurdish Politics and Protest in Turkey, Seattle: Washington University Press.

\section{NOTES}

1. In the period 2000-2005, the PKK faced severe internal problems, related to political and ideological reorientation. An expression of the internal turmoil and upheaval, was the break-way of a group of PKK cadres under the leadership of two members of the Presidential Council and a number of long-time militants (among them the former representative for Europe). They established a new political party: Partiya Welatparez Demokratik (Patriotic Democratic Party or PWD). Between 2003 and 2005 an estimated total of 1500 militants left the PKK. In 2004, Öcalan called for the formation of a 'Preparatory Rebuilding Committee', concerned with the refounding of the PKK as a distinct party. The reconstruction congress was held from March 28 to April 4, 2005, as the ninth congress of the PKK, and marks the PKK's rebirth (see for an extensive discussion Akkaya and Jongerden 2011: 149-50).

2. More on the Kurdish movement's engagement with the Global Justice Movement can be found in Watts (2010) and Casier (2011).

3. BDP is the legal political party considered a sister-party of the PKK. It gathers a broad range of individuals with different affiliations and is the predecessor of different Kurdish parties that were subsequently closed down on the charges of advocating separatism and/or supporting a terrorist organization. With the June 2011 elections, when its candidates ran as independents so as to circumvent the $10 \%$ threshold, BDP became the $4^{\text {th }}$ biggest party in the Turkey's General Assembly. BDP also runs more than 100 municipalities in the Southeast of the country, where its main competitor is the AKP.

4. See the elaboration on the competition with the AKP in Casier, Jongerden and Walker 2011.

5. For a detailed account of Öcalan's ideological discourse on the 'New Man' see Grojean 2008. 